\title{
Exploring the implementation of FonF tasks from learners' perspective: a study on young learners
}

\author{
Neda Moezzipour ${ }^{1}$ and Amir Rezaei ${ }^{2,3^{*}}$
}

\author{
* Correspondence: \\ Rezaei.amirr@gmail.com \\ ${ }^{2}$ Department of Language and \\ Literacy, University of Malaya, Kuala \\ Lumpur, Malaysia \\ ${ }^{3}$ Faculty of Education, University of \\ Malaya, 50603 Kuala Lumpur, \\ Malaysia \\ Full list of author information is \\ available at the end of the article
}

\begin{abstract}
This study reports on the investigation of young learners' perceptions of FonF tasks regarding enjoyment, ease, performance, and persuasion. It was attempted to explore young learners' attitudes toward FonF tasks in two elementary English classes. The two classes consisted of 13 and 17 female learners aged 12 to $15 . \ln$ particular, the present study addressed the learners' perceptions of two selected tasks of grammar interpretation and grammaring. For this purpose, questionnaires and an interview were used to elicit their perspectives on the tasks. Based on the analysis of their responses, it was revealed that the determinant features for their preferences fall into five categories: the use of context in teaching grammar, the use of contextual support for practicing the grammatical structure, task demands, the novelty of procedures, and the saliency of linguistic structure. Findings also indicated that in spite of the learners' positive attitudes toward four tasks, variations existed in their perceptions regarding four sources of influence: the required mental processes to do a task, opportunities for group works, textual enhancement and the learning values of the task.
\end{abstract}

Keywords: Focus on form, Task, Grammar interpretation, Grammaring, Interest

\section{Introduction}

Putting the emphasis on the formal aspects of language, the pendulum of language teaching methodology started its journey with Grammar Translation and Audiolingual Method both of which involved attempts to teach learners grammar, differing only in how it is to be accomplished (Ellis 1997). But presenting discrete items of grammar to learners did not guarantee to learn a language the way natural languages are acquired. After that, the field of language teaching emphasized the need for more communicative practices. The strong version of CLT was grounded on the assumption that "linguistic knowledge is acquired through communication rather than direct instruction" (Ellis, et al. 2001a, p. 407). The proponents of CLT believed that "comprehensible input and the exclusive use of meaning-oriented tasks were necessary and sufficient for language acquisition" (Laufer and Girsai 2008, p. 694).

However, the issue remained unsolved. It became evident that one-dimensional focus on the meaning-based features of language hinders learners from attaining linguistic accuracy. Furthermore, the learners' incapability of coping with sociolinguistic aspects

(c) 2016 The Author(s). Open Access This article is distributed under the terms of the Creative Commons Attribution 4.0 International License (http://creativecommons.org/licenses/by/4.0/), which permits unrestricted use, distribution, and reproduction in any medium, provided you give appropriate credit to the original author(s) and the source, provide a link to the Creative Commons license, and indicate if changes were made. 
of language (Ellis et al. 2001b), giving precedence to meaning rather than form which stemmed from the Processing Instruction (Van Patten 2002) and Ellis's warn against the risk of fossilization (2003a) triggered the need for some form of instruction which could pave the way for learners to achieve grammatical competence while trying to get their meaning across. This led to the emergence of Focus on Form (FonF) as a reconciliation of form and meaning integration in the course of instruction.

FonF is now considered as a burgeoning field of study, and it has been practiced in many ESL as well as EFL contexts. Therefore, inspecting learners' perspectives toward implementing FonF can shed light on the effectiveness of this kind of grammar instruction in the classroom. Also, the ongoing ubiquity of FonF calls on a need to make it clear which FonF tasks can appeal to learners and best motivate them in the process of learning. Apparently, if they feel motivated internally, the instruction would lead to better results. The present study seeks to focus on the learners' perceptions of FonF tasks to find out how to increase their level of motivation and interest to engage in learning.

\section{Review of literature}

\section{Focus on form approach}

As commented by Vaez Dalili (2011) the field of language teaching pedagogy has witnessed a resurgence of interest in the pivotal role of grammar instruction. As discussed above, this could be traced back to the difficulties learners experienced and the fact that they could not gain high levels of proficiency in language as well as not acquiring native-like productive skills as a result of unresolved errors made by learners in communication in classrooms (Shamsudin et al. 2012). In addition, theoretically, FonF goes in tandem with psycholinguistic accounts of L2 acquisition such as Van Patten's Processing Instruction, Schmidt's Noticing Hypothesis and Swain's Output Hypothesis which played a central role in the appearance of new approaches to SLA.

According to Van Pattern's Processing Instruction, the focus is on the meaning and learners' process input for meaning before they process it for form. Content words are processed in the input before grammatical form. He does not reject the idea of grammatical instruction but believes that grammatical forms should be practiced in a communicative context in performing different tasks. On the other hand, based on Swain's Output Hypothesis the focus is on the learners' language production and getting feedback on the ungrammatical forms for enhancing what they have learned. By producing something, the learner tests his/her hypothesis about language forms and receives feedback from an interlocutor. Therefore, based on output hypothesis, language production enables learners to enhance and internalize linguistic knowledge. Schmidt (1994) claims that learners' intake out of the received input is more important than the input itself and input, alone, is not sufficient for language acquisition. He asserts that there is not any intake without noticing. Noticing is closely related to focus on form framework. Noticing makes learners pay attention to grammatical forms while engaged in communicative activities, which is considered as a FonF practice.

As put forth by Ellis (2005) neither theory nor research could account for a unified proposal of how to include grammar instruction in the syllabus, and so the controversy goes on. The ongoing challenge between meaning-focused and form-focused approaches 
in language teaching methodology culminated in the emergence of new standpoints which strove for a reunification of form-meaning interaction. The reawakening of interest in the attention to form is attributed to Michael Long. He defined Focus on Form (FonF) as "drawing students' attention to linguistic elements as they arise incidentally in lessons whose overriding focus is on meaning or communication" (Long 1991, pp. 45-46). However, it is necessary to make a distinction between FonF and FonFS. As Sheen (2002) put it, the controversy revolves around the degree teachers need to direct the students' focus to linguistic features while keeping the need to communicate. As he went on to say, while FonF entails incidental attention to linguistic features in the communicative context, FonFS is equated with "traditional teaching of discrete points of grammar in separate lessons" (Sheen 2002, p.303). Ellis (2006) defined FonF as an approach which "entails a focus on meaning with attention to form arising out of the communicative activity" (p.100).

The FonF in this study is an implication based on the above-mentioned categorization of form-focused instruction which has been put into practice in the mold of FonF tasks namely Grammar Interpretation and Grammaring.

\section{Grammar interpretation}

The tasks selected for this study has been adopted from a larger project which was conducted by Shak and Gardner (2008). According to the writers, the key feature of the task is noticing. This is compatible with Schmidt \& Frota's noticing and noticing-thegap hypotheses (1986) which states that in order for input to become intake, learners are required to go to the target features of the input and make comparisons between their current state of linguistic competence (in their output) and the target language (input).

As Ellis (1997) stated, one of the ways to structure the input is interpretation tasks which are designed to invite learners to get engaged in intentional learning by consciously noticing how a target pragmatic expression is used in the input. These tasks are specially designed to contain many exemplars of the structure. Therefore, the activities in grammar interpretation (GI) tasks are sequenced to require first attention to meaning, then noticing the form and function of the grammatical structure, and finally error identification (Ellis 2003b).

The GI tasks in this study conform to these criteria since learners attend to meaning to notice the function of the grammatical structures in use. Then, they interpret the meaning of the texts leading to the restructuring their mental grammar. The tasks were used to teach past passive forms. Learners were shown several pictures and, they were asked to select the sentence that described each picture.

\section{Grammaring}

Grammaring is a term coined by Larsen-Freeman which as Hamilton (2007) noted tries to encapsulate the dynamic nature of grammar. Larsen-Freeman (2003) claimed grammaring is 'the fifth skill, the ability to use grammar structures accurately, meaningfully, and appropriately.

Criticizing the previous static views of grammar (descriptive grammar, prescriptive grammar, pedagogical grammar), Larsen-Freeman (2003) emphasized the importance of grammaring, an approach in which teaching grammar is less "knowledge-centered" (p.24). Grammaring tasks can be good choices for a FonF syllabus because, in addition 
to Larsen-Freeman conceptualization of teaching grammar, they are in line with Swain's output hypothesis (1985); they are production-oriented tasks which present grammar to learners as a skill or process to engage with language. Shak, in her study (2008), asserted that a grammaring task acts as a means to unfold learner language and enables appropriate and meaningful discourse within a communicative context.

\section{Examining interest through a different lens}

The prominence of English as an international language has led many students around the world toward learning it either as a part of their formal education or as an extracurricular activity. Among these students, some are internally motivated to get involved in the activity and others are required to do so. This is the distinction that Ellis (2008) made between intrinsic and instrumental motivation. Motivation as a psychological construct came under close examination since it was believed that it could improve our understanding of the learning process by shedding light on the affective as well as cognitive aspects of learning such as learners' thoughts and attributions or the situationspecific factors like the effect of environment in which learning takes place. However, Tin (2013) commented that the notion of motivation no longer satisfactorily explains learning English in various contexts. Instead, she proposed the concept of interest as a subcomponent of the term 'motivation' which can be "a pedagogically valuable alternative lens that could enrich our understanding of students who have studied English as a formal school subject and have developed an interest in learning English as a foreign/ second language" (Tin 2013, p. 130).

In educational psychology, interest is now widely accepted as an important motivational variable that could contribute to unfolding the affective as well as cognitive aspects of learning. Its role in helping the students engage in the learning activity and nudging them toward better cognitive performance cannot be denied; as acknowledged by Hidi and Renninger (2006), the level of a person's interest powerfully influences attention, goals and levels of learning and it also increases effort, persistence, and academic motivation.

Interest can be defined as a motivational variable which "refers to the psychological state of engaging or the predisposition to re-engage with particular classes of objects, events, or ideas over time" (Hidi and Renninger 2006, p. 112).

In a community where English is considered a foreign language and is taught either in schools as a subject matter or in private language institutes, there is a dire need to gain insight on how to increase learners' interest to help them engage in the process of learning. Furthermore, the application of a cost- effective approach is crucial since efforts should be made to optimize the learning opportunities.

In the same vein, the prominence of FonF instruction in recent years has prompted many studies in the field to investigate different facets of this new approach to language teaching (e.g., Farrokhi and Gholami 2007; Shamsudin and Karim 2013; Saiedi and Safay Moheseni 2011). However, as stated by Poole (2005), FonF instruction though examined vastly through experimental lens has been left undescribed using the original definition proposed by Long (1991) who argues that "form should be attended to on a need-to-know basis in a spontaneous manner, forms to focus on should not be pre-planned and sequentially presented, and forms should be attended to within meaning-driven situations" (Poole 2005, p.77). 
With reference to all the data obtained from the body of research and considering the general trend in SLA domain which emphasizes the role of instruction in learning, there is little doubt on the effectiveness of FonF in language learning. But beyond all the supporting evidence which signifies the facilitative role of FonF, the affective side as to what aspect of this approach to grammar instruction can generate interest and push learners in better learning has been left untouched.

Attending the affective side of the learning coin in children's education deserves even closer scrutiny since the materials and the context of teaching are of high importance for these learners who are at the outset of their learning journey. They should be motivated and encouraged to learn when putting in the classroom context. Therefore, the teaching approach and the type of tasks and materials should be selected with utmost care and attention, for the better outcome will be achieved along with a positive attitude toward the task at hand.

\section{The present study}

The present study seeks to bring light on the appropriateness of incorporating FonF in young learners' syllabi by assigning a role to the learners for evaluating their learning and expressing their perceptions and attitudes toward two FonF tasks. Besides, the study tries to illuminate what features of a FonF task can best generate interest in learners to get more involved in the process of language learning. The significant point which is under scrutiny is finding out about how learners felt toward implementing FonF tasks in the English classroom and how they perceive this new approach to grammar instruction. Also, by investigating the four elements of enjoyment, ease, performance, and persuasion, it is attempted to explore their attitudes on carrying out the FonF tasks. The affective side of learning has been paid considerable attention in recent years as a corollary to the growth of humanistic and learner-centered approaches. This study is also conducted to determine the feasibility and effectiveness of this type of instruction from learners' perspectives.

\section{Research questions}

To achieve the purpose of the study, the following research questions were proposed:

1. How do young learners evaluate the FonF tasks in terms of enjoyment, ease, performance and persuasion ${ }^{1}$ over the two- day lessons?

2. What aspects of FonF tasks lead to the emergence of interest in young learners?

\section{Methods}

\section{Participants}

The participants in the study were English learners who studied in a private language school in Sabzevar, Iran. Two intact classes were selected as the site for data collection. The 30 learners in these classes were all females of 12 to 15 years old who were studying at elementary levels. All the participants were learning English as a foreign language. Their first language was Persian. In Iran, at higher education, the males and females can co-educate, but in the secondary schools and private language schools, due to cultural issues and religious beliefs, they cannot co-educate; consequently, they can only attend single-gender classes. The instructional approach and the language content 
of lessons were the same for both classes. Since the learners' English proficiency level (EPL) was not a primary variable in this study, the students' previous English scores gained in the institute tests were the basis for categorizing them into three groups of low, mid and high proficient learners. According to the institute decree, the scores between 70 and 75 fell into low proficiency group, 75-90 were considered as mid-proficient learners, and 90-100 were categorized as high -proficient ones. This rough estimation of EPL was solely utilized to confirm the heterogeneity of the two groups. Hence, the sample could be a better representative of the English language learners, from low- proficient learners to high proficient ones.

\section{Instrumentation}

To achieve the necessary data for the study, two FonF tasks were utilized. As mentioned in the Shak \& Gardner' study (2008), 'noticing' is the hinge upon which FonF tasks operate to afford a chance for learners to center their attention on grammatical structures while they are engaged in the process of conveying the message. A distinguishing characteristic of the tasks was their division into different sections to make it possible for the learners to express which parts of the tasks they liked or disliked (which in fact corresponds to their level of interest). Each section had specific features which could provide the opportunity for the researcher to determine what specific features in a task made it preferable for the learners. These sections are shown in Table 1.

An attitude questionnaire was also distributed among learners at the end of each lesson. Since the class time was limited, they could take it home to have time to contemplate on the questions. The questionnaire included both open and closed questions. The closed questions comprised four items which asked the learners to express their ideas on each task regarding enjoyment, ease, performance and persuasion with three degrees of yes, not sure and no. The open questions contained items which focused on the aspects of each task the learners liked or disliked.

At the end of the course of the study, a final interview was conducted by the researcher at the end of the study when the learners took their final exam. All learners were put in groups to be encouraged to take part actively in the interview. First of all, to elicit their opinions on FonF tasks, they were asked if they saw this way of learning grammar as worthwhile or not. With their responses, the interview entered the next

Table 1 Features of FonF tasks, adapted from Shak and Gardner (2008)

\begin{tabular}{ll}
\hline Feature & Function \\
\hline Just Wondering & $\begin{array}{l}\text { The preliminary part of each task was 'just wondering' in which the new grammatical } \\
\text { form was introduced to the learners in the context of a story. More contexts for further } \\
\text { exposure were provided in a teacher-led discussion. } \\
\text { In this section, activities were provided to give the learners the chance to deal with } \\
\text { the linguistic form to draw their attention to the grammatical structure and thus help } \\
\text { the acquisition of the form take place. } \\
\text { The outstanding attribute of this part of the tasks was affording the learners with an } \\
\text { opportunity to manipulate the grammatical form while interacting with their peers in } \\
\text { small groups. } \\
\text { This activity guided the learners to formulate a rule about the correct use of the } \\
\text { grammatical form. } \\
\text { In this section which was the end of the tasks, learners had to produce the target } \\
\text { language structure in written form. }\end{array}$ \\
\hline
\end{tabular}


phase. They were mostly enquired about what features of the task made them interested in doing them. The questions that were asked during this semi-structured interview were about what specific features of the task the learners liked or disliked.

\section{Procedures}

The researchers also acted as the teacher in both classes. The semester comprised 15 sessions which were held over eight weeks. However, the experiment started in the seventh session when the students had acquired the introductory skills in English. Therefore, they were more prepared to do the tasks which were communicative.

The main aim of the current research was to investigate the perception of the learners after treatment; therefore, for this purpose, each task was comprised of two lessons which were supposed to be implemented on two separate days. On each day, the learners were asked to fill the questionnaires at the end of the lesson and comment on the specific parts of the tasks which were under focus on that day; therefore, each task was commented on two days.

In each day, a particular FonF task, which introduced a specific grammatical structure, was carried out in the classroom. In the first lesson, which is devised as day one in the tasks, the crux of the tasks was arranging a context to introduce the target form. Therefore, on day one, the effort was focused on affording a suitable context in which enough input could be presented to the learners; however, on the next lesson, it was attempted to make learners produce an output which required the use of previously acquired target forms. Moreover, since the learners were supposed to comment on different aspects of the task, this could give more possibility to reflect on different sections and give responses to the questionnaire with more awareness.

\section{Results and discussion}

1. How do young learners evaluate the FonF tasks in terms of enjoyment, ease, performance and persuasion over the two- day lessons?

The first part of the questionnaires distributed among learners after each lesson included four questions which learners responded to on all eight days. Enjoyment, ease, performance and persuasion referred to items $1,2,3$ and 4 respectively. Item 1: I enjoyed doing this activity; item 2: I think this activity was easy; item 3: I think I did well in this activity and item 4: I want to do more activities like this. The questionnaires were filled on both days, and the learners' responses were scored on a three-point Likert scale based on the options of $1-$ No, 2 - Not sure and 3 - Yes. The calculated means are shown in the following graphs. The figures which show a point above 2 illustrate the learners' positive attitudes (Fig. 1).

The focus of GI tasks was past passive form which was a totally new linguistic form and somewhat a more complicated one. Although a decrease can be observed in the enjoyment level on the second day, the mean values of 2.9 and 2.7 (SD: 0.3, 0.5) reveal that the pleasure students received by doing the task was quite high. On the first day, one student commented: 


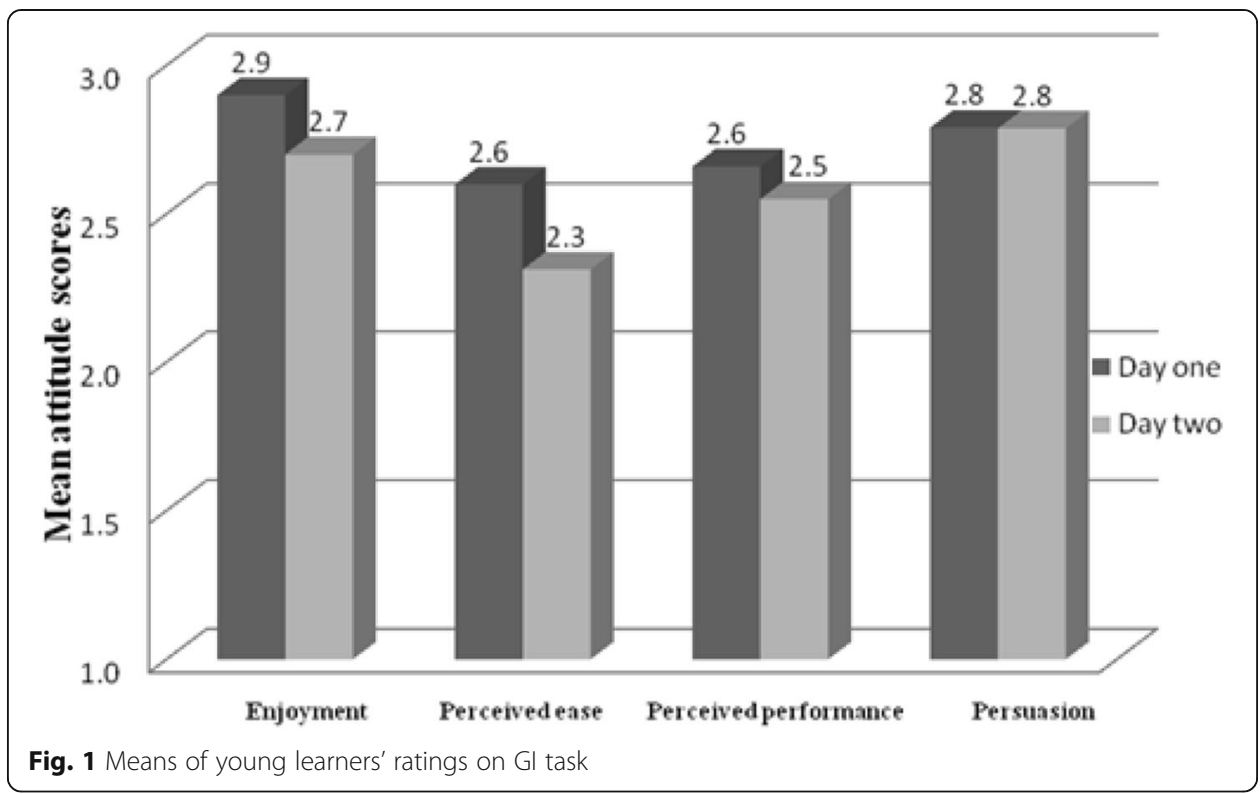

${ }^{2}<$ I like the pictures. When I read the sentences just below the picture, and I compare the sentences with the picture, I can understand better what passive is and how it is formed. It's fun, and it helps you learn better $>$ (S21).

On day two, the same student wrote:

$<$ I like the activity, but I don't know so many words to fill in the blanks. That's why I liked the activity I did yesterday better, and I enjoyed doing it much more >.

This fact could also be seen in the perceived ease level. The mean value for ease was 2.6 on day one (SD: 0.5$)$ which dropped to $2.3(\mathrm{SD}=0.7)$ on the second day.

The lower perceived task ease might be rooted in the total newness of the concept of passive for the learners and also the productive demands of the task on day two which forced students to make passive forms.

The cause of the learners' decreased interest was the output requirement of these tasks which was cognitively demanding. On day one, the task consisted of the pictures which helped the students to understand the concept of passive sentences and how to form them but the learners' responses showed a feeling of disappointment with the task demands on the second day.

Interestingly, even if the level of enjoyment, perceived ease and performance altered over the two days, no significant change was observed in the level of persuasion. This fact implies the efficacy of FonF and the learners' tendency to get involved in such ways of learning grammar.

The results for grammaring tasks are as shown in Fig. 2.

By looking at the results, it is revealed that between the two tasks, grammaring gave the lower mean value for the four factors on day one. In spite of the low statistical values, some learners in the interview corroborated that they liked grammaring and they enjoyed doing it. Here is a part of the interview:

T: Why did you enjoy Moody Mimi and the gang the most? 


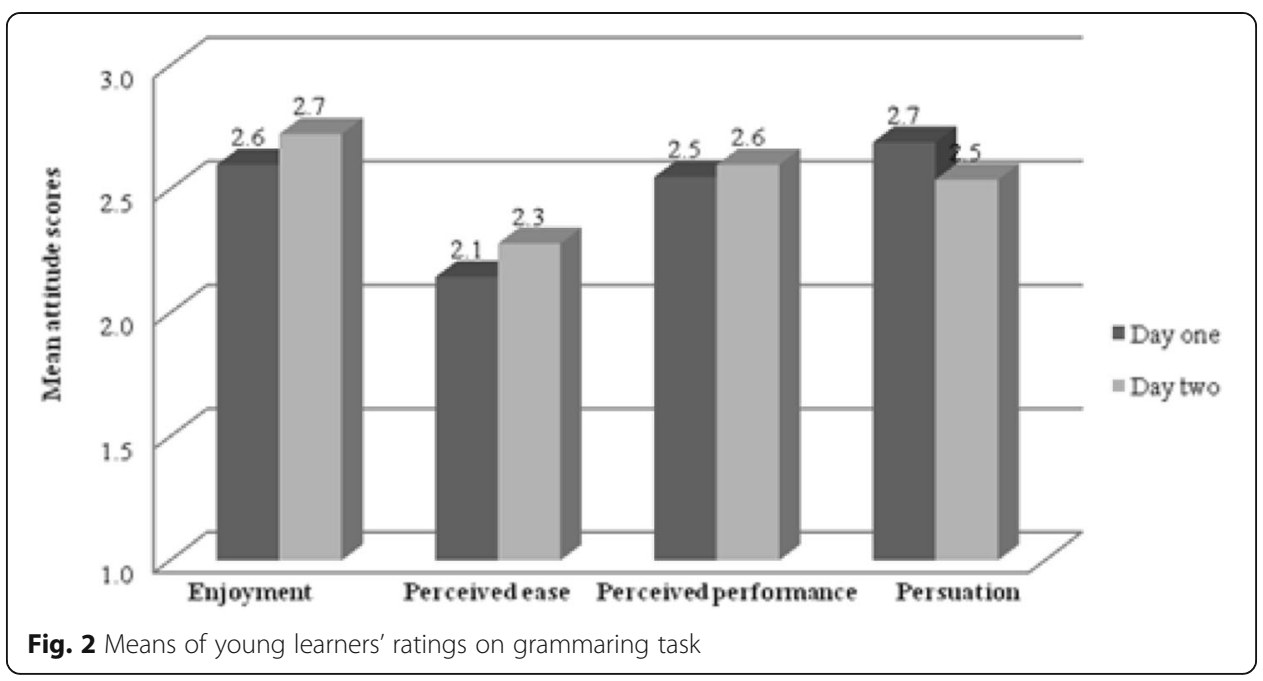

$S:$ It was fun.

$<$ It would be interesting to write a story even in Persian, let alone in English. I enjoyed writing sentences in English $>$.

Unlike GI tasks (Fig. 1) which received a decrease in the perceived ease level on day two, a quite remarkable increase can be observed in the ease level of the grammaring task from day one to day two. Given the productive demand of the task on the second day, the results were expected to be vice versa. However, it was implied from the learners' questionnaires and interviews that this increase can stem from the practice opportunity the task provided for the learners to learn new words and make sentences in English.

Not surprisingly, the performance level was higher on the second day too. This goes in tandem with the increase in learners' self-confidence and the fact that they managed writing in English. In the interview, a learner put it this way:

\section{$<$ liked Moody Mimi and the gang because I could write in English. I even showed my brother my story. I was very proud of writing in English $>$.}

Given all the advantages the learners counted for the grammaring task, it was surprising to see a decrease in the persuasion level on day two. According to the learners' responses in the interview, it seemed that the productivity demand of the task on two days had caused the decrease in the learners' motivation to get involved in similar tasks for their future learning. On the day of interview, the answer was partly found in the learners' responses:

\section{$<$ It was a good activity but if you want to teach grammar using such activity, it would be hard to understand $>$.}

Despite the fact that most students showed disappointment with the writing requirement of the tasks, still, grammaring tasks turned out to be appealing to the learners. This indicates that when these young learners felt that they were able to put their sentences into English, they experienced more confidence and for that matter, their enjoyment level rose too, culminating in an increment in performance level as well. 
Based on the coding of learners' responses to the interviews and questionnaires, the researchers identified five categories which incorporated the reasons why the learners liked or disliked a task:

As shown in Table 2, the majority of learners (30\%) reacted to the instructing grammar within a communicative context. For example, they mostly focused on the use of stories as a helpful way of teaching which helped them better understand the grammatical rule and made them more willing to follow the instruction. Some of them also referred to this point that instruction would be more beneficial if it is done implicitly as it was in the FonF tasks where teaching was embedded in the context of stories which gave the learners an opportunity to work on some other skills as well. They also believed that discussions at the beginning of each lesson were advantageous because they could get an insight of how the rule was formed during the discussions.

Task demand was another characteristic which was frequently referred to in the learners' responses. Although there were some productive tasks among learners' favorites, it was quite evident that those tasks which require less production are more probable to fall into learners' favor. This might pertain to the language proficiency of the learners. The impact of cognitive processing on the learners' preferences was also pointed out in Shak \& Gardner's findings (2008).

The novelty of procedures had also a double-sided effect on the learners. Some students referred to the differences between what they had at school and their experiences with FonF tasks. Although some learners liked the new procedures to go through to accomplish a task goal, some disliked it since they thought it needed heavier cognitive processes.

The role of familiarity with the linguistic feature was also dubious; for a group of students, the earlier knowledge of grammatical feature lead to higher rating of the task in terms of enjoyment, ease, performance and persuasion, whereas for some other learners, the former acquaintance with the linguistic feature in focus resulted in lower mean values for the aforementioned criteria. Therefore, the choice of linguistic form is of high importance as well.

2. What aspects of FonF tasks led to the emergence of interest in young learners?

Answering the second question, in the first stage, needed focusing on the learners' responses to the second part of attitude questionnaire which included 'write one thing you liked about the activity' and 'write one thing you did not like about the activity'. As noted in the instrumentation section, the four FonF tasks were divided into various parts, so that the learners' responses to each of the statements corresponded to one of these parts. Therefore, it was easier to focus on the features of the task that encouraged

Table 2 The coded determinant features for the learners' task preferences

\begin{tabular}{lc}
\hline Inductive Category & Percentage \\
\hline The use of context in teaching grammar & 30 \\
The use of contextual support for practicing grammar & 28 \\
Task demands & 22 \\
The novelty of procedures & 8 \\
The saliency of focused linguistic structure & 12 \\
\hline
\end{tabular}


the learners to get engaged in the tasks (see Table 1). The overall findings are summarized in Table 3.

Noticing was mostly referred to by the learners on day one (GI $70 \%$, Grammaring $60 \%$ ). Their comments show that most of them had a positive view of this part which prepared them cognitively to engage in the task. Some of the comments are presented here:

\section{GI}

Like:

\section{$<$ Comparing the pictures in two parts, I could understand active and passive much} better $>$.

Dislike

$<$ I did not like writing the sentences; because I did not know the rule well and this bothered me >.

\section{Grammaring}

Like:

$<$ Matching the sentences with the pictures.... It was fun to do it with hands $>$.

Dislike:

$<$ The text messages had many new words $>$.

Meanwhile, the least percentage of reference was given to Just Wondering which changed from $3 \%$ for grammaring on the second day to $10 \%$ for GI on day one. Although this feature did not receive much attention, there were some cases that explained the reasons for learners' liking or disliking for the two tasks:

Table 3 The percentages of commented task features

\begin{tabular}{lllll}
\hline Task type & Task feature & Referred to by (\%) & Like (\%) & Dislike (\%) \\
\hline Gl & Just wondering & 13 & 75 & 25 \\
Day One & Noticing & 70 & 86 & 14 \\
& Grammar Detective & 17 & 80 & 20 \\
Gl Just Wondering & 10 & 33 & 67 \\
Day Two & Jctivity & 30 & 44 & 56 \\
& Writing & 60 & 44.5 & 55.5 \\
Grammaring & Just Wondering & 7 & 100 & - \\
Day One & Activity & 33.5 & 62.5 & 37.5 \\
& Noticing & 53.5 & 80 & 20 \\
& Writing & 40 & 45 & 55 \\
Grammaring & Just Wondering & 3 & 100 & - \\
Day Two & Activity & 30 & 44 & 56 \\
& Writing & 67 & 40 & 60 \\
\hline
\end{tabular}


GI

Like:

$<$ It was interesting to make a story and say what has happened in the story $>$.

Dislike:

$<$ I did not like the first part because I could not talk about an event $>$.

Interestingly, there was no negative attitude among those learners who commented on Just Wondering in grammaring tasks. Here is an example of the given comments:

$<$ The start of today lesson was interesting. When my friends shared their messages with the class, the atmosphere of the class changed $>$.

One notion that was evidenced in the data was the importance of scaffolding and small group interaction in the process of learning which has been emphasized repeatedly in the socio-cultural perspectives of second language acquisition. Mitchell and Myles (2004) contended that "children's early language learning arises from processes of meaning-making in collaborative activity with other members of a given culture" (p. 200). As verified by the collected data, the Activity section which encouraged learners to work with their peers was mentioned as stimulating and more interesting. The percentage showed $45 \%$ preference for GI day one and $65 \%$ for grammaring day two. A part of the final interview shows the students' positive views clearly:

T: Sometimes, you had to work with your friends. Was it easier on your own or with your friends?

S1: <With my friends.>

T: Why do you think it was better?

S1: < Because when we work with our friends, if we don't know a word or we have problems, we can ask our friends $>$.

S2:

$<$ I agree with her. When we work in groups, we learn much better. Even in these activities, when working with our friends, we could do even those activities which were more difficult $>$.

Notwithstanding the general tendency toward group work, it was manifest that those students who had a better command of English leaned less toward working with their friends. Acting in the form of groups sounded disturbing and confusing for them as echoed in the learners' attitudes.

And for the last feature, writing, it was observed that although many of learners disliked production of a piece of writing on their own, the ratio of those who saw it worthwhile is remarkable too. A variety of comments were given by the learners, considering this section:

Like:

$<$ I like writing stories. Please add some writing parts to the activities $>$. 
Dislike:

$<$ Writing stories is interesting, but I did not know much grammar and vocabulary to do the activity well >.

Overall, the learners' comments echo the general observation that writing is the most difficult skill since, regarding the production aspect, it is considerably demanding.

Based on the analysis of the learners' responses those features which seemed to influence their interest in implementing FonF tasks revolved around four main pivots which are illustrated in Table 4.

The mental processes the learners go through to achieve a task goal has an influence on their perceptions of the task. This relates to the cognitive burden a task puts on their mind. The difficulty of linguistic structure, the level of required vocabulary to accomplish the task or the expected output could be all included in this category. As for the required output, the general observation showed that those parts which needed much production were more likely to get the learners' negative attitude. However, even writing sections which had the most productive demand were rated positively by many students. Those were either the proficient learners who could manage writing or speaking in English; or the middle-proficient ones who attained a sense of self-confidence and success by producing English output. For other learners, the production part fell into disfavor which shows such parts should be used with utmost caution. The findings, also, revealed that there was a preference for gap-filling activities across writing sections. This might be due to the fact that it will be easier for the learners to accomplish the task goal and attain self-confidence.

Textual enhancement such as the use of pictures; as emphasized by Sharwood Smith (1993) increased the quality of input through input enhancement. The use of images as visual input and boldfacing in these tasks did call learners' attention and made them willing to engage in the tasks.

It was evidenced that those sections which gave the learners a chance to practice other skills were seen as more worthwhile. It was mentioned by some students that the opportunity to work with their hands, as in grammaring, or the chance to practice working with the dictionary made them more willing to engage in the task and this caused them to see the task as more beneficial and appealing. They believed if the focus of an activity was not just on teaching a certain grammatical rule, they were more interested in doing the task. It has also been evidenced in the previous studies that learners hold a multi-faceted vantage point toward tasks i.e., how to perform the activity, moral of the story, general language skills, and personal and social development are among the factors which influence how they define a worthwhile task (Shak and Gardner 2008, p. 402).

Table 4 The influential task features based on the learners' responses

\begin{tabular}{ll}
\hline Inductive Category & Percentage \\
\hline The required mental processes to accomplish the task goal & 30 \\
Opportunities for group work & 25 \\
Textual enhancement & 27 \\
The learning values of the task & 18 \\
\hline
\end{tabular}




\section{Conclusion and pedagogical implications}

In the light of the present study findings, a new facet to the effectiveness of incorporating FonF instruction into young learners' syllabus was revealed. Their positive ratings of FonF tasks illustrate the appropriacy of including FonF tasks into young learners' curriculum. This can be an answer to the quandary of how to teach grammar since the present study sought to examine the issue through assigning an evaluative role to the learners. The high ratings showed their positive attitudes toward FonF tasks which culminated in a high level of interest followed by more engagement and better learning. Yet, this does not offer a sufficiently desirable solution to the dilemma as what aspects to focus on while implementing FonF instruction.

Given the assumed acquisitional potential of FonF, the question now arises as to how to best create an instructional environment in which the learning can take place in its utmost level while the adjustments of the focus on either meaning or form can also occur in its best possible way. Firstly, it appeared that those tasks which push the learners to work beyond their level of proficiency affected their perceptions of the task negatively. Therefore, when it comes to planning the tasks for learners of this age, it should be noticed how much cognitive load is required for task completion. This point should be considered both in determining the task required output and deciding on the linguistic feature; in both phases, in fact, the cognitive demand should be taken into account. The choice of focused grammatical structure is also highly important in that it should not be much above or below the learner's proficiency level.

Also, the findings showed that a feature which significantly affected their attitudes was the use of pictures. From a pedagogical point of view, this suggests the broad use of contexts such as telling a story or use of pictures in designing tasks for this age group.

Another important factor was how the learners viewed themselves. Those tasks which needed production such as grammaring could improve their perceptions of themselves as learners of English. Though it seems to be beneficial for those who have gained the feeling of accomplishment, it might be disappointing for those who are less proficient. Hence, it should be borne in mind that such tasks should be used cautiously, trying to devise a production level for each specific learner in order to help him/her increase his/her self- confidence as a foreign language learner.

An implication can be made based on the fact that the learners' perceptions of tasks were influenced by the opportunity provided for them to work in groups. It was observed that learners had a remarkable preference for those sections in which they had to share what they were doing with their friends. This suggests that in the case of difficult tasks such as writing, to help the learners, the procedures required to fulfill the task goal can be spiced up with peer work so that little cognitive burden is imposed upon the learners.

The researchers in the field have put their efforts into shedding light on the effect of FonF instruction on learning, and some have tried to investigate the learners' conceptions of FonF instruction, whether in young learners (Shak and Gardner 2008) or adolescents (Shamsudin and Karim 2013). This study was also an effort to illuminate the issue and reveal the intricacies involved. Hence, the findings can be helpful for both task designers and teachers who are looking for the best way of including formal instruction in the syllabus. Different facets are deciphered so that optimum results can be attained. 


\section{Endnotes}

${ }^{1}$ In the study conducted by Shak and Gardner (2008), the term 'motivation' was used to refer to the students' tendency to engage in similar tasks in future. In the present research, the author has replaced this term with persuasion in order to avoid confusion with motivation as a cover term for interest.

${ }^{2}$ The sentences between $<>$ marks are translated from Persian.

\section{Authors' contributions}

The research was a collaborative effort between both authors and both authors cooperated in the completion of this research. NM designed the study and reviewed the literature and helped in reporting the results. The second author, $A R$, helped in, analyzing data, reporting and discussing the results. Also, writing the introduction, implications and conclusions was the result of collaboration between two authors. Both authors read and approved the final manuscript.

\section{Competing interests}

The authors declare that they have no competing interests.

\section{Author details}

${ }^{1}$ Department of Language Education, Alzahra University, Tehran, Iran. ${ }^{2}$ Department of Language and Literacy, University of Malaya, Kuala Lumpur, Malaysia. ${ }^{3}$ Faculty of Education, University of Malaya, 50603 Kuala Lumpur, Malaysia.

Received: 8 May 2016 Accepted: 6 October 2016

Published online: 13 October 2016

\section{References}

Ellis, R. (1997). SLA research and language teaching. Oxford: OUP.

Ellis, R. (2003a). Designing a task-based syllabus. RELC Journal, 4(1), 64-81.

Ellis, R. (2003b). Task-based language learning and teaching. Oxford: OUP.

Ellis, R. (2005). Principles of instructed language learning. Asian EFL Journal, 7(3), 9-24

Ellis, R. (2006). Current issues in the teaching of grammar: an SLA perspective. TESOL Quarterly, 40(1), 83-107.

Ellis, R. (2008). The study of second language acquisition (2nd ed.). Oxford: OUP.

Ellis, R., Bausterkmen, H., \& Loewen, S. (2001a). Learner uptake in communicative ESL lessons. Language Learning, 51, $281-318$.

Ellis, R., Bausterkmen, H., \& Loewen, S. (2001 b). Preemptive focus on form in the ESL classroom. TESOL Quarterly, 35, 407-432.

Farrokhi, F., \& Gholami, J. (2007). Reactive and preemptive language related episodes and uptake in an EFLclass. Asian EFL Journal, 9(2), 58-92.

Hamilton, N. (2007). Grammaring business English. www.besig.org/events/conf2007/downloads/Hamilton.doc. Accessed 10 March 2011

Hidi, S., \& Renninger, K. A. (2006). The four-phase model of interest development. Educational Psychologist, 41(2), 111-127.

Larsen-Freeman, D. (2003). Teaching Language: From grammar to grammaring. Boston: Heinle.

Laufer, B., \& Girsai, N. (2008). Form-focused instruction in second language vocabulary learning: a case for contrastive analysis and translation. Applied Linguistics, 10, 1-23.

Long, M. H. (1991). Focus on form: a design feature in language teaching methodology. In K. de Bot, R. Ginsberg, \& C. Kramsch (Eds.), Foreign language research in cross-cultural perspective (pp. 39-52). Amsterdam: John Benjamins.

Mitchell, R., \& Myles, F. (2004). Second language learning theories (2nd ed.). London: Hodder Arnold.

Poole, A. (2005). The kinds of forms learners attend to during focus on form instruction: a description of an advanced ESL writing class. Asian EFL Journal, 7(3), 75-87.

Saiedi, M., \& Safay Moheseni, P. (2011). Teachers' use of preemptive versus reactive focus on form across proficiency levels. Procedia- Social and Behavioral Sciences, 29, 1797-1806.

Schmidt, R., \& Frota, S. (1986). Developing basic conversational ability in a second language: a case study of an adult learner of Portuguese. In R. Day (Ed.), Talking to learn: conversation in second language acquisition (pp. 237-322). Rowley: Newbury House.

Shak, J. (2008). Using grammaring tasks with young ESL learners to engage with language. www.hku.hk/clear/ala/doc/ abstract. Accessed 10 February 2011.

Shak, J., \& Gardner, S. (2008). Young learners' perspectives on four focus on form tasks. Language Teaching Research, 12(3), 387-408.

Shamsudin, S., \& Karim, H. R. (2013). Implementation of focus on form: teachers' and students' conceptions. ProcediaSocial and Behavioral Sciences, 70, 1265-1274.

Shamsudin, S., Karim, H. R., \& Hamzah, M. (2012). The typology, characteristics and distribution of focus on form episodes (FFEs) in an EFL context. Procedia - Social and Behavioral Sciences, 66, 507-517.

Sharwood Smith, M. (1993). Input enhancement in instructed SLA. Studies in Second Language Acquisition, 15, 165-179.

Sheen, R. (2002). Focus on form' and 'focus on forms'. ELT Journal, 56(3), 303-305.

Swain, M. (1985). Communicative competence. In S. Gass \& C. Madden (Eds.), Input in second language acquisition (pp. 235-253). Rowley: Newbury House.

Tin, T. B. (2013). Exploring the development of 'interest' in learning English as a foreign/ second language. RELC Journal, 44(2), 129-146. doi:10.1177/0033688213488388.

Vaez Dalili, M. (2011). On the integration of form and meaning in English language teaching (ELT): an overview of current pedagogical options. Procedia - Social and Behavioral Sciences, 15, 1217-1221.

Van Patten, B. (2002). Processing instruction: an update. Language Learning, 52(4), 755-803. 